\title{
ARTICLE
}

\section{Innovation System LARAKU NYATA (Population Administration Service for Persons with Disabilities) Bulukumba Regency}

\section{OPEN ACCESS}

Citation: Andi Fitriyani Yahya, ST. and Alsry Mulyani, S.E, M.Si. , Innovation Administration Service for Persons with Disabilities) Bulukumba Regency. Ijori Journal Vol. 1 No. 1 (2021): 27-32. Journal Vol. 1 No. 1 (2021): 27-32.
https://doi.org/10.52000/ijori.v1i1.6

e-ISSN : 2775-7641

Accepted: February $25^{\text {th }}, 2021$

(c) The Author(s)

\section{cc) (1)}

This work is licensed under a Creative Commons Attribution-NonCommercialShareAlike 4.0 International License.

\author{
Andi Fitriyani Yahya, S.T..$^{{ }^{\star}}$, Alsry Mulyani, S.E, M.Si..$^{2^{\star}}$ \\ ${ }^{1,2}$ Regional Research and Development Planning Agency of South Sulawesi Province | Urip Sumoharjo \\ Street No. 269 Makassar \\ 凶afitriyani7475@gmail.com¹, alsrymulyani736@mail.com²
}

\begin{abstract}
Population documents generated from the population administration process are the right of every citizen, this is inversely proportional to Indonesian citizens with disabilities, this can happen for several reasons, including difficulty accessing services, the view that people with disabilities are not important to have documents. Population and the lack of information related to disabilities in the population administration process, so that this is the background for innovation, so that persons with disabilities have the right to have a residency identity. The method used in this research is descriptive conducted interviews with several resource persons with qualitative analysis, the results obtained show that there is an increase in the number of persons with disabilities who already have e-KTPs increased sharply from 2016, the ownership of e-KTPs from 85 people, increased to 223 people in early 2018.
\end{abstract}

Keywords: population identity, innovation, administrative services, disabilities, government programs

\section{Preliminary}

Population documents generated from population administration are the right for the people of goodness, as stated in Article 2 of Law Number 23 of 2006 concerning Population Administration which has been converted into Law Number 24 Year 2013 on the Amendment of Act Number 232006 concerning Population Administration (hereinafter referred to as the Adminduk Law). Population documents such as National Identity Card (KTP), Family Card (KK), and Birth Certificate are very important, because they are often a prerequisite for obtaining other public services. For example, KTP is a requirement for obtaining a business license or birth certificate as a condition for school registration. Apart from population documents, the rights of the community related to Adminduk include getting the same services in population registration and civil registration, protection of personal data, and legal certainty of document ownership. According to (Firdaus, Ferry, and Fajar Iswahyudi, 2010) that state protection for citizens and society must be developed and facilitated without discrimination.

Reports from (Badan Pusat Statistik, 2016) that Indonesia had 6,008.661 mental disability which is $2.45 \%$ of the total population of Indonesia, persons with disabilities consists of blind 1.7802 million inhabitants, 472855 impaired mental disabilities, speech disabilities 164,690 people, with mental disabilities 402,817 people, 616,387 people with physical disabilities, 170,220 people with disabilities, with multiple disabilities 2,401,592 people. 
It needs to be done to change the image of society towards people with disabilities as stated (Taylor, 2009) states that the culture of minority groups must not only survive in a liberal democracy, but must also be recognized in the dominant culture in the process of mutual recognition interactions. Recognition itself begins with "self-image" politics. As a group that represents and reflects their own faces, they have the challenge of turning negative views into positive ones by themselves. According to (Eny Hikmawati, 2004) Persons with disabilities psychologically will experience a sense of inferiority and difficulty in adjusting to society, because they treat the community or the environment in the form of reproach or compassion when looking at them. The problems faced by persons with disabilities in Indonesia include the lack of access to information on the importance of rehabilitation, lack of public facilities that make it easier for persons with disabilities to carry out their daily activities and lack of access to jobs for persons with disabilities (Eny Hikmawati, 2004)

According to (Edi, 2008) Public administration service in Indonesia tends to have several fundamental problems. Apart from the relatively low effectiveness of organizing and public participation in service delivery, public services also do not have a complaint and dispute resolution mechanism. As a result, the quality of service products has not satisfied its users.

Service Related Disability Administration of Civil Registration (Adminduk Capil) Persons with disabilities are a group of people who are vulnerable to unfulfilled rights (Kiser, Larry L. and Stephen L. Percy. (1980). This happens because some because, among others, the difficulty of accessing services, the view that persons with disabilities are not important to have population documents, and a lack of information regarding disabilities in the population administration process (LAN 2008). Even though the rights of persons with disabilities are specifically mandated in the Adminduk Law, Law Number 25 of 2009 concerning Public Services (Law on Public Services), and Law Number 8 of 2016 concerning Persons with Disabilities.

Although persons with disabilities have the right to the services of Capil adminduk which are guaranteed to be fulfilled by the state, in practice they are often neglected. This occurs because the resistance experienced people with disabilities, due to no availability of access to physical facilities for persons with disabilities; the unavailability of disability friendly services; and there is a stigma in the family and society that persons with disabilities do not need identity or residence documents.

No access physical facilities can be found in buildings / government offices or public services that do not provide the user the incline for wheelchair, making it difficult to reach the higher floors of the building in question. Meanwhile, the unfriendly services for persons with disabilities include the unavailability of assistants or sign language translators needed by deaf persons, so they are unable to communicate and obtain information optimally. Meanwhile, the negative stigma most often affects persons with mental disabilities, who are often ridiculed and considered incapable of the law, making it increasingly difficult to fulfill their rights as citizens. These various obstacles make it difficult for persons with disabilities to process and obtain residence documents.

In Bulukumba, there are 1,018 people with disabilities. 8.34 percent of them do not have e-KTPs, 75.24 percent do not have KKs and 60.12 percent of their children do not have birth certificates. The reason for their recording of e-KTPs was that internally the family closed access for family members with disabilities to take care of their own population administration. The fact is that one of a family with a disability, someone is shackled by his family and is not allowed to interact with other communities. There is still a traditional view of society towards family members with disabilities which is considered a curse and others should not know. In addition, supporting equipment is still limited to reach people with disabilities (Addlakha, Renu. And Saptarshi Mandal, 2009)

There are even people with severe disabilities who have been neglected and have lived alone since their parents died, but their names have never been included as recipients of social assistance such as the National Health Insurance. After being analyzed, the cause was not having a KTP and not being recorded in any family card. Even after checking with the local Dukcapil Office, the person concerned is never recorded as having a Population Identity Number (NIK)".

The reason is when the Bulukumba community tries to register there is a tendency for persons with disabilities or assistants who help fill out the data form to be reluctant to write information on disabilities because they are ashamed or think that they do not need to write it down. In addition, not all persons with disabilities who already have a Population Identity 
Number (NIK) are registered as persons with disabilities. This problem is caused by three things, namely: first, because persons with disabilities or their families feel ashamed to admit the existence of a disability, so they do not write it down; second, persons with disabilities or their families are not aware of the data column, and the clerk did not remind them to fill them in, who may also not know because their disabilities are invisible; and third, there is a change in conditions, from non disabled to disabled, but not or have not made changes to the data related to the condition of the disability.

Because it is considered important to eliminate all barriers for persons with disabilities bag, through provider physical facilities that are easy to reach, providing friendly services for people with disabilities, including providing tool assistance, as well as eliminating negative stigma on persons with disabilities to always look to the advantages of every person with disabilities in their activities. Persons with disabilities also should deemed capable or provided reasonable accommodation to be able to report him to obtain residence documents.

Troubleshooting problems of disability in the district Balakumba, government through the innovation of Population Administration for Persons with Disabilities, or "Adminduk Inclusive". This innovation is the response of the Population and Civil Registration Service in meeting service standards without discrimination. Services are carried out in an integrated manner, in the form of easy access to biometric recording of e-KTP for persons with disabilities. Services that include data collection, pickup, and biometric recording services for e-KTP. The data collection was carried out by the Social Service, and the pickup was carried out by PPDI and PMI Bulukumba Branch. Post service, the Health Office and BPJS then take on the role of recommendations and issuance of BPJS Health cards. For those with disabilities are given the ease of excellent service without following the requirements of the queues and file previous recording has been verified by the operator.

\section{Research Methods}

The method used in this research is descriptive method using qualitative analysis. The descriptive method is a way to describe how innovation is used by conducting interviews and discussions with various parties, the interviews and discussions are carried out to the local government of Bulukumba who is directly involved in the research, namely persons with disabilities, families of persons with disabilities, representatives of the village office, representatives sub-district office, representative of population service.

\section{Results and Discussion}

\subsection{Regional Government Data Collection for Persons with Disabilities in Bulukumba Regency}

Based on the results of interviews and discussions with local government data obtained Total Project ah Bulukumba residents of 2016 amounted to 435810 inhabitants of which there are 1,018 mental disability or 0,23 percent. Of the total population of that there are 133378 head of family which there are families persons with disabilities of 206 family card.

Of the 84.27 percent of the population who already have e -KTPs, only 85 persons with disabilities are registered in the Population Administration Information System (SIAK) version 6.0 application and already have e-KTPs. Meanwhile, based on data from the Bulukumba Regency Social Service, there are 1,018 people with disabilities. The low number of persons with disabilities who have identity to occupation is due to the lack of awareness and active participation of the community in reporting people with disabilities in their respective neighborhoods, the difficulty of citizens with disabilities to access the basic right to have an e-KTP; and limitations of residents with disabilities in carrying out biometric e-KTP records

\subsection{Factors Affecting Persons with Disabilities Do Not Have A Identity Country}

The facts show that residents of Bulukumba district who experience disabilities are found shackled in the house and this shackling is carried out by the family, it turns out that this person does not have a population identity and is even excluded from the family card. This happens because of several factors that cause, namely:

First, there is the public opinion that families with disabilities do not need to have an identity. This assumption is given by the community due to the lack of role played by persons with disabilities in neighboring activities, people who think that people with disabilities have an average SD-SMP education. So that it forms the mindset of people who think in such a way with the lack of support for education that people with disabilities deserve to be treated like normal people in general.

Secondly, many families in Bulukumba district who have family members with disabilities are considered to have low social status. This mindset formed from the public perception that lack of respect 
for the existence of persons with disabilities, so that the impact on the family members of persons with disabilities. There is a need for government and community efforts that understand the importance of respecting persons with disabilities to provide education and eliminate perceptions about persons with disabilities.

Third, there is concern that family members are lost to family members with disabilities, so that people with disabilities must be shackled to stay at home and not embarrass other family members. This kind of attitude can make family members with disabilities feel discouraged about going through life.

The problem of people with disabilities, according to (Eva Rahmi Kasim, 2011), must be seen as something universal and comprehensive. Universal and comprehensive in the sense that disability is a reasonable condition in any society, therefore policy makers must also consider that the needs of persons with disabilities are the same as those of other citizens by integrating persons with disabilities in all OLICY regarding all aspects of life. (Satya Arinanto, 2008).

Based on the description above, there are two main points that need to be resolved. Namely, only 225 people with disabilities have e -KTPs so that access to basic service fulfillment is still low and community participation in reporting people with disabilities in their respective neighborhoods is still low. From the two main points above, it affects the achievement of ownership of e-KTP for persons with disabilities and population registration of vulnerable population of population administration in a cumulative manner as regulated in Regulation of the Minister of Home Affairs Number 11 of Year 2010 concerning Guidelines for Population Data Collection and Issuance of Population Administration Vulnerable Populations.

\subsection{The Strategy of the Bulukumba Regional Government so that People with Disabilities in Bulukumba Regency Get a Identity Country}

The local government of Bulukumba district made a strategy to be able to solve the problem of people with disabilities who have not yet obtained a population identity, this strategy is expected to have a clear impact by increasing people with disabilities in order to obtain a population identity, namely through the innovation of Population Administration for Persons with Disabilities, or "Inclusive Adminduk. ".

This innovation is the response of the Department of Population and Civil Registration in meeting service standards without discrimination. Services are carried out in an integrated manner, in the form of easy access to biometric e-KTP recording for persons with disabilities. Services that include data collection, retrieval and service commitment At $A B C$ nan-el recording of biometric ID cards. Data collection is carried out by the Department of Social, pick-up was carried out by PPDI and PMI Bulukumba Branch. Postservice, the Health Office and BPJS then take on the role of recommendations and the issuance of BPJS Health cards. For persons with disabilities who are provided with excellent service without having to follow queues and previous file registration requirements have been verified by the operator.

\subsection{Results of the Bulukumba Regional Government's Innovation with the Implementation of Population Administration Services for Persons with Disabilities}

Before the innovation was implemented, people with disabilities did not get population administration services, they were considered trivial, service rights were not fulfilled. After the Inclusive Admin innovation is implemented, all residents without exception have equal access to population administration services. The number of people with disabilities who have KT Pel has increased sharply from 2016, the ownership of e-KTPs from 85 people, increased to 223 people in early 2018. Through cross-sector cooperation, persons with disabilities can also access free medical treatment, free education, house renovation assistance, and other social assistance. Internally, the Department of Education and Civil Registration has documentation of population data based on the type of disability and increases the cumulative ability of e -KTP ownership.

This can make it easier for the Department of Population and Civil Registration when they want to see population data for disabilities, with this data the Department of Population and Civil Registration can process it for the benefit of the community. This is to fulfill the rights of every citizen to be entitled to a resident identity.

\subsection{Benefits after the Innovation in the Application of Population Administration Services for Persons with Disabilities}

First, for the government, with this innovation, data collection can be carried out accurately according to the data in population documents. So that the rights of every Indonesian citizen to have a population identity are fulfilled. Both advantages for local governments 
have been present in providing service residence rights to people with disabilities. This is stated in the law on the rights of persons with disabilities mandated specifically in the Adminduk Law, Law Number 25 of 2009 concerning Public Services (Law on Public Services), and Law Number 8 of 2016 concerning Persons with Disabilities.

The third is as material for local governments in formulating development policies, including regional policies in poverty alleviation. As the government tries to alleviate poverty from all elements of society.

Fourth, with this innovation the government can expand the scope of services for providing e-KTP for the people of Kab. Bulukumba , so that the rights of every citizen of Bulukumba district can be equalized, with the existence of an e-KTP for residents with disabilities in Bulukumba district, Persons use resident identity as the basic condition for processing public services including, Services can get a BPJS card as a condition for health services, Persons with disabilities can actively participate in political life to choose and be selected, Persons with disabilities can process education and skills training as well as other assistance from the Social Service, Persons with disabilities can get assistance in the form of wheelchairs, crutches, sewing machines and other assistance.

Fifth, the advantages for persons with disabilities in the presence of this innovation is The existence of innovation from the ministry of administration has provided official identities for people with disabilities to have access to the fulfillment of rights as a citizen, especially in health, Education and social assistance are expected to help with with disabilities to be able to have a better life.

\section{Conclusion and Suggestions}

Based on the results of the research, it can be concluded that the Population Administration Service Innovation for Persons with Disabilities can run well, this can be seen how the steps taken by the local government of the Bulukumba district to alleviate the problem of at least people with disabilities, residents of Bulukumba district who have not received a population identity facility. With the provision of services that include data collection, pickup, and biometric recording services for e-KTP. The data collection was carried out by the Social Service, and the pickup was carried out by PPDI and PMI Bulukumba Branch. Postservice, the Health Office and BPJS then take on the role of recommendations and issuance of BPJS Health cards. For people with disabilities, excellent service is provided. The results of this innovation is seen that the increase on the number with disabilities who have a KTP-el increased sharply from 2016 ownership of VAW-el of 85 people, up to 223 people at the beginning of 2018.

Suggestions for local governments to always understand that the Inclusive Adminduk innovation is not an innovation planned for the short term. This innovation will not stop until all persons with disabilities in Bulukumba Regency have a population document and civil registration in the form of e-KTP, family card, and birth certificate. So it needs to be done continuously until all persons with disabilities in Bulukumba district are registered as Indonesian citizens.

\section{Acknowledgments}

The authors would like to thank people with disabilities in Bulkumba district, families of people with disabilities in Bulukumba district, the local government of the Population and Civil Registration Service, as sources and for the opportunity so that this scientific work can be completed. Thanks also to the local government for the data provided to support this research. And all parties involved cannot be named individually.

\section{References}

Addlakha, Renu. dan Saptarshi Mandal (2009). Disability Law in India: Paradigm Shift or Evolving Discourse Economic and Political Weekly. vol 44. No41/42.

Arneil, Barbara. Disability, Self Image, and Modern Political Theory (2009). Political Theory. Vol 37 No. 2.

Arinanto, Satya. Hak Asasi Manusia dan Transisi Politik di Indonesia. Jakarta: Pusat Studi Hukum Tata Negara FHUI, 2008.

Badan Pusat Statistika (2016), "Data Disabilitas Indonesia", Kabupaten Bulukumba, Provinsi Sulawesi Selatan.

Edi Suharto, Penerapan Kebijakan Pelayanan Publik Bagi Masyarakat Dengan Kebutuhan Khusus. Disampaikan pada Focussed Group Disscusion "Kajian Penerapan Pelayanan Khusus (Service for Customers with Special Needs) pada Sektor Pelayanan Publik, Lembaga Administrasi Negara, Sahira Butik Hotel, Bogor 9 -10 Oktober 2008.

Eny Hikmawati dan Chatarina Rusmiyati, Kebutuhan Pelayanan Sosial Penyandang Cacat, Jurnal Informasi Volume 16 Nomor 1 Tahun 2011, hal 18 
Eny Hikmawati dan Chatarina Rusmiyati, Op.Cit, hal 19.

Eva Rahmi Kasim. (2011). Pedoman-Pedoman WHO tentang Rehabillitasi Berbasis Masyarakat Jurnal. Bandung.

Firdaus, Ferry, dan Fajar Iswahyudi. 2010. Aksesibilitas Dalam Pelayanan Publik Untuk Masyarakat Dengan Kebutuhan Khusus. Jakarta: Pusat Kajian Manajemen Pelayanan LAN RI.

Kiser, Larry L. \& Stephen L. Percy. (1980). "The Concept of Coproduction and Its Implication for Public Service Delivery". Paper presented at the 1980 Annual Meetings of the Society for Public Administration, on April 13-16. Indiana University Bloomington.

LAN. (2008). Kajian Pelayanan Untuk M a s y a r a k a t D e n g a n Kebutuhan Khusus. Jakarta; LAN RI 